\title{
The Variability in Management according to the Quantum Physic
}

\author{
Stefania Allegra \\ Atlantic International University \\ Department of Education \\ Faculty, Honolulu, Hawaii, United State
}

\begin{abstract}
The management is a process that can lead to discover the most important physic principles as the variability; and the analysis on the Schrodinger's cat, etc. Here we focus about what a manager must face if he or she wants to go on in the management field in order to achieve goals. You are what you think and what you decide to be. Everything comes out from mind, and your thoughts generate the reality. If you want to manage the life, before you must manage yourself. To know variabilities is to understand what it's going to happen in life. So through analysis of all variabilities we can get the best results in management. Every person must focus the fact that thoughts, words and actions must be together, with no opposition. The variability is determined by external and internal facts, it means that the inner self world influence all the results of the life. So all changes come when we are able to change our inner self world, and it's a math result all will change around yourself. And the power of the mind is another important point that produce the attraction law, all you think but in no contradiction create the present result of life. What you think must be in positive and in focalization of real points of the life. What we ask must be not the thing to avoid but the thing must bring the best desired result we want to achieve.
\end{abstract}

Keywords: Management, Business, Administration Quantum physic, variability, Schrodinger's cat, Psychology of the management, Prof. Dr. W. Edwards Deming

\section{Introduction}

Management is the power of goals to achieve in life. A person who knows how to manage the life it becomes very strong in mind, body and spirit.

So it's important to discover what the management is really.

The management is also the mirror of the culture of the country when we are talking about middle and small companies, it's very different when we talk about multinational companies, they are a different reality.

Theory serves to provide a relation for decision making.

In my researches I focus my studies about the quantum physic and about how the inner self intention about our conscience can influence the result of our external life.

\section{The Variability in Management according to the Quantum Physic}

The quantum Mechanics has produced the influence in the way we look at everything around us.

It's the classical physics that lead all the quantum mechanics. In fact the classical physics expresses that we see the position of an object we are able to determine it's what we see in that moment and it could be the opposite too. This is the Isaac Newton theory.

Another important theory was discovered by Werner Heisenberg with the so called Heisenberg's Uncertainty principle. So he stated 
that if we measure the position of a particle and it happens that the less exactly we can determine it's momentum and the opposite.

The momentum of a particle is equal to its mass times and velocity so this is the result in energy measurement and uncertainty in the time interval. 1

At the same time when we act making a measurement of the particle we influence the result of the measurement. So this is the reason because we determine our reality. This is the thought experiment theory of the Schrondinger's cat where he shows how all realities are possible. The cat could be dead or alive, this state was so called the quantum superposition. Schrondinger called the thought experiment the entanglement. This is the quantum interpretation applied to everyday objects. 2

According to the real life decisions for managers and leaders there is the same principle. In many moments of the life it's easier not to take any decision. When a manager must take a decision it's obvious as professional you must follow a process. We can refer to the principle issued by W. Shewhart so called Statistical Process Control. He affirms that a process can be influenced by variations. So change is normal in life it's the result of being alive. According to variations you can produce variations so you can produce the same. So people life as a company is influenced every moment by variations and from the possibility to achieve goals. We can focus two kind of variations, one is controlled and the second type of variations is uncontrolled. So the best choice to do is to try to control the uncertain to look at all directly and have a choice. 3

We can remind an important theory from Prof. Dr. W. Edwards Deming. He underlines some main points, exactly 4 , as following: 1) try to improve the service giving a better design; 2) it's very important to test the product to have sure results and to sell it in global markets. He invented the so called "System profound knowledge" where he focuses some very important components as to appreciate a system, to understand a variation, the psychology and epistemology. Deming became very important in Japanese market for the strong economic power. He got the Deming Prize in 1951 in Japan. He became very famous after his death.

I personally teach a special course addressed to all managers "How to discover the own life force. The $K i$ or prana", it's a discovering of the Self, and the management processes in variabilities. It's my last Italian publication in this book publication "S. Allegra - Come scoprire ed esprimere la propria forza vitale. Il Ki o Prana. Armando Curcio Editore- (S. Allegra- How to discover and express the own life force. The Ki or Prana. Armando Curcio Publisher- ) I teach this course in my centre A.S.D. - S. ALLEGRA DOJO, and Nuova Atena Martial Arts Research studies and Yogasattva Research Institute, Scientific Research Institute in via Francavilla 371 Taormina (Me) Italy, www.groupnuovaatena.com and www.allegradojo.com. The course is taught at the top of the volcano Etna too once a month and in other locations in foreign countries according to the request, it's a wonderful experience where you can discover hidden power of yourself and start to manage a different life style. It's a course that can change your life and your company revenue.

If you need to book your powerful course you can call Secretariat office +393493060250 .

\section{Conclusion}

In conclusion, managers must focus on different issues in order to achieve goals in management.

Firstly it's very important to have clear vision about the reality of the company. Then it' $s$ necessary a focalization in potential negative implications. All must be fixed in an action plan to organize the steps to do and avoid missing points.

So management is to put union among what we think, say and act, if one of these points is in opposition, nothing will happen about the management goals expected. 
Find the power in yourself to manage your whole life.

\section{Notes}

1. https://www.quora.com/What-is-thesignificance-of-Heisenbergs-UncertaintyPrinciple visited on July 11st, 2018.

2. https://en.wikipedia.org/wiki/Schrödinger $\% 27$ s_cat visited on July 12nd, 2018.

3. https://en.wikipedia.org/wiki/W._Edwards _Deming visited on July 12nd, 2018.

4. https://www.intelligentmanagement.ws/un certainty-choice-quantum-mechanics-formanagers-leaders/ visited on July $16^{\text {th }}$, 2018 .

\section{Biography}

Stefania Allegra was born on January $6^{\text {th }}, 1973$ in Taormina. She lives in Taormina (Me) Italy. She lived in Vienna Austria because of some studies and she felt a very important connection with the Nordic life. In fact she has got a Nordic DNA discovered through the DNA researches. She graduated in Foreign languages and Modern Literatures. After she got some Masters, i.e. Master in International Human Resources; Master in Hotel \& Resort Management; Master in Interpretation for Parliamentary Interpreters and Translators and International Organizations; Master in Teaching Oriental, Rare and Foreign languages; Master in Business Administration (MBA).

She got the $\mathrm{PhD}$ - Doctor in philosophy in Administration and Management at AIU University USA. She is going to get the Postdoctoral in Administration and Management too.

She has been managing the Nuova Atena company in Italy where she teaches Administration and Management at all levels. She has been teaching at university at the degree course for interpreters and translators. She teaches in different foreign and rare languages.

She is Entrepreneur, Business Administration and Management Professor, Foreign languages Professor and Linguist, Court translator and
Interpreter, Conference Interpreter, Writer and Researcher, Literary Agent. She's a researcher in many fields for example in Business Administration and Management, in rare languages, in psychology, in quantum physic too, etc..

\section{She has been a professional writer since 2006.}

Publications: 1. S. Allegra, La psicologia dello yoga applicata al parto - Mursia; 2. S. Allegra, Grossesse et Yoga- pratique, physiologie et psychologie appliqué à la femme enceintePréface de Geeta Iyengar -Les Editions de l'Eveil-Budo Editions, France; 3. S. Allegra, Come scoprire ed esprimere la propria forza vitale. Il Ki o Prana, Armando Curcio Editore.

\section{She is in progress about other next publications.}

\section{Acknowledgements}

I say thanks to the Atlantic International University, Department of Education Faculty, Honolulu, Hawaii, United State, and in particular to Dr Franklin Valcin, Department Dean, Dr Jack Rosenzweig, Department director, Dr. Edward Lambert, Academic Coordinator and all other professional contacts.

A special thanks to the Prof. Dmitry Pashin, Vice Rector of Kazan Federal University, Director of Open Institute of Innovation technological and social development, with his important advice.

Thanks to my colleagues in my all professional environments.

Thanks to my son Damian and family.

\section{References}

[1] Bell, The school as an organisation: A reappraisal. British Journal of Sociology of Education, 1980.

[2] L. e Deal, T. Bolman, Modern approaches to understanding and managing organizations, 1984. 
[3] L.G. Bolman and Deal, T. E., Reframing organizations: Artistry, choice and leadership, 1991, 1997.

[4] M. Brundrett, What lies behind collegiality, legitimation or control? Educational Management and Administration, 1998.

[5] T. Bush, Theories of educational management, 1986.

[6] T. Bush, Theories of educational management: Second edition, 1995.

[7] T. Bush, Organisational culture and strategic management. In D. Middlewood and J. Lumby (Eds.), Strategic Management in Schools and Colleges, 1998.

[8] T. Bush, Crisis or crossroads? The discipline of educational management in the late 1990s. Educational Management and Administration, 1999.

[9] T. Bush., Theories of educational management: Third Edition, 2003.

[10] T. Bush, The National College for School Leadership: A successful English innovation, 2006.

[11] T. and Glover, D. Bush, School leadership: Concepts and evidence, 2002.

[12] G. Campbell-Evans, A values perspective on school-based management, 1993.

[13] Chapman, J., Leadership, school-based decision-making and school e activeness, 1993.

[14] L. Cohen, Manion, L. and Morrison, K., Research methods in education (5th Ed.), 2000.

[15] Cohen, M. D. and March, J. G, Leadership and ambiguity: The American college president. Boston: The Harvard Business School Press, 1986.

[16] Copland, M., Darling-Hammond, L., Knapp, M., McLaugghlin, M. and Talbert, J., Leadership for teaching and learning: A framework for research and action. New Orleans: American Educational Research Association, 2002.

[17] L. Cuban, The managerial imperative and the practice of leadership in schools, 1988.
[18] Green eld, T. B., Organisations as social inventions: rethinking assumptions about change, Journal of Applied Behavioural Science, 1973.

[19] Green eld, T. B., Organisation theory is ideology, Curriculum Enquiry, 1979.

[20] D. Gri ths, The case for theoretical pluralism, Educational Management and Administration, 1997.

[21] C. Handy, C., Understanding Organizations, 1993.

[22] C. Hodgkinson, Foreword, in T. B. Green eld and P. Ribbins (eds.). Green eld on Educational Administration, 1993.

[23] E. Hoyle, The Politics of School Management, Hodder and Stoughton, 1986.

[24] T. and Keough, T. and Tobin, B., Postmodern Leadership and the Policy Lexicon: From Theory, Proxy to Practice, Paper for the Pan-Canadian Education Research Agenda Symposium, 2001.

[25] K. Leithwood, D. and Steinbach Jantzi, R., Changing Leadership for Changing Times. Buck- ingham: Open University Press. Of educational management, 1999.

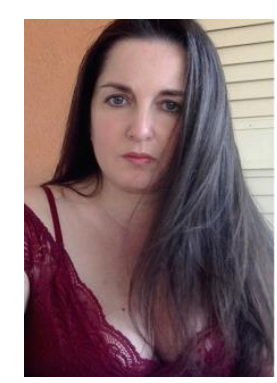

Prof. Dr. Allegra Stefania photo 